\title{
Lung carcinoma in the era of personalized medicine: the role of cytology.
}

\author{
Maureen F Zakowski \\ Memorial Sloan-Kettering Cancer Center \\ Marluce Bibbo \\ Thomas Jefferson University Hospital
}

Follow this and additional works at: https://jdc.jefferson.edu/pacbfp

Part of the Medical Anatomy Commons, Medical Cell Biology Commons, and the Pathology Commons Let us know how access to this document benefits you

\section{Recommended Citation}

Zakowski, Maureen F and Bibbo, Marluce, "Lung carcinoma in the era of personalized medicine: the role of cytology." (2012). Department of Pathology, Anatomy, and Cell Biology Faculty Papers. Paper 98.

https://jdc.jefferson.edu/pacbfp/98

This Article is brought to you for free and open access by the Jefferson Digital Commons. The Jefferson Digital Commons is a service of Thomas Jefferson University's Center for Teaching and Learning (CTL). The Commons is a showcase for Jefferson books and journals, peer-reviewed scholarly publications, unique historical collections from the University archives, and teaching tools. The Jefferson Digital Commons allows researchers and interested readers anywhere in the world to learn about and keep up to date with Jefferson scholarship. This article has been accepted for inclusion in Department of Pathology, Anatomy, and Cell Biology Faculty Papers by an authorized administrator of the Jefferson Digital Commons. For more information, please contact: JeffersonDigitalCommons@jefferson.edu. 


\section{Editorial}

As submitted to:

Acta Cytologica

And later published as:

\section{Lung Carcinoma in the Era of Personalized Medicine: The Role of Cytology}

2012;56:587-589

\section{DOI: $10.1159 / 000345183$}

Maureen F. Zakowski a Marluce Bibbo b

a Department of Pathology, Cytopathology Service, Memorial Sloan-Kettering Cancer Center, New York, N.Y.,

b Department of Pathology, Anatomy and Cell Biology, Thomas Jefferson University, Philadelphia, Pa. , USA

In 2004, three groups working independently [1-3] , almost simultaneously, reported remarkable findings: that activating mutations in the epidermal growth factor receptor $(E G F R)$ were common in certain lung carcinomas and that these mutations correlated with the response of those lung tumors to therapy with gefitinib and erlotinib, both EGFR tyrosine kinase inhibitors (TKIs). This was the first time driver mutations in lung cancer that responded to targeted therapy had been identified, marking the beginning of a new era of personalized medicine in lung cancer. Prior to the discovery of these mutations, patients had been treated with EGFR TKIs but predicting who would respond and who would not was only imperfectly correlated with the histologic appearance of the tumor and the clinical profile of the patient.

The lung cancer landscape has rapidly shifted in less than a decade since these discoveries. Pathology now drives treatment selection with the knowledge that there are histology-specific mutations and treatment agents readily available [4] . Departments of pathology have responded 
by refining criteria for the separation of nonsmall cell lung cancer (NSCLC), increasing the size and scope of diagnostic molecular laboratories and collaborating with clinical colleagues on an unprecedented level.

The search for new, targetable mutations in lung cancer has resulted in discoveries and frustrations and dramatic changes in the pathology practice. In this evolving scenario some questions seem relevant: where does cytology fit into this new era? How is the practice of cytology poised to ask and answer the necessary questions? How does the cytologist do 'more and more with less and less'? We know that most lung cancer patients present with advanced disease and that diagnosis will be made on cytology and small biopsy specimens [5] . According to the 2012 National Comprehensive Cancer Network (NCCN) guidelines [6] , the first step in the therapy for recurrent or metastatic NSCLC is the establishment of histologic subtype and the second step is testing for $E G F R$ mutations and $A L K$ fusions yet nowhere is the word cytology even mentioned. In some of these patients, the only diagnostic and analyzable material is the one obtained from an FNA biopsy.

In an attempt to guide the cytopathologist and offer strategies to navigate this new territory, this issue of Acta Cytologica, devoted to lung cancer, brings together data and techniques from international experts in the field of diagnosis, testing, epidemiology, new discoveries, and markers, and offers a multidisciplinary approach to these questions. New technologies are also highlighted, showing just how much can be done with limited material.

We begin this special issue by looking at data that supports the use of FNA in the diagnosis and classification of both primary and metastatic lung tumors, with the ability of cytology to classify the vast majority of NSCLC into adenocarcinoma or squamous carcinoma. This first step is crucial in matching the appropriate tumor samples to the appropriate testing or therapeutic agents. Adams and $\mathrm{Wu}$ [7] demonstrate this high accuracy in a retrospective examination of over 1,000 cases. If cytomorphology alone is inadequate tor the subclassification of NSCLC, immunocytochemical staining takes on more importance. Johnson et al. [8] conclude that the use of Dako TTF-1 antibody paired with Leica Napsin A antibody as a double stain yields the best result for diagnosing adenocarcinoma. Additionally, using the Leica Napsin A as a single stain resulted in the highest positive predictive value of $97 \%$ for adenocarcinoma. Once the subtype of carcinoma is determined, the NCCN guidelines recommend that all adenocarcinomas, large cell carcinomas, and NSCLC not otherwise specified be tested for targetable molecular abnormalities in EGFR and ALK. In fact, this has led to the use of a new, nonpathologic term, 'nonsquamous histology', favored by clinicians to indicate what lung carcinomas should be tested and to guide therapy, as bevacizumab and pemetrexed are to be avoided in squamous cell carcinoma patients due to inefficacy and toxicity, respectively. This term nicely demonstrates the interplay, usually but not always welcome, between pathologists and clinicians in the practical triage and treatment of lung cancer. Assigning mutation status in lung cancer is increasingly possible at the immunocytochemical level. As Moreira and Hasanovic [9] demonstrate, new mutation-specific antibodies can be employed as an alternate or adjunct to standard molecular testing using limited cytology material. Antibodies to the EGFR exon 19 deletion mutant and the EGFR L858R mutant can be used in material that has undergone decalcification and that may be unsuitable for 
molecular testing. More recently, a sensitive antibody to ALK suitable for the detection of EML4-ALK has been made available [10]. How this will play a role in the determination of ALK fusion status and the selection of crizotinib as appropriate therapy compared to fluorescent in situ hybridization (FISH) has yet to be determined. As more molecular testing is translated into mutation-specific antibodies, we can expect expanded application to cytology material. FISH is a powerful tool in the field of predictive marker analysis in cancer and is increasingly useful in the study of lung cancer. Savic and Bubendorf [11] provide an overview of the current role of FISH in respiratory cytology pointing out that it has become the gold standard in the identification of $A L$ rearrangements. With the discovery of novel gene fusions involving the tyrosine kinases ROS1 and RET as additional driver mutations in NSCLC [12] , FISH methodology becomes increasingly essential.

Turning to the technical aspects of molecular testing, Roy-Chowdhuri et al. [13] demonstrate the first semiautomated, computer-guided laser capture microdissection (LCM) of cytology specimens using SIVQ and AutoScan as a first step in integrating LCM into clinical cytomolecular testing. Arcila [14] outlines a simple protocol for obtaining DNA from archival cytology material that is currently in use at the Memorial Sloan-Kettering Cancer Center (MSKCC) where hundreds of cytology specimens including cell blocks, fluids, ThinPreps, and direct smears have been analyzed for molecular abnormalities. Elnekave and Thornton [15] provide an overview of how the interventional radiologist, working as part of a team that includes cytotechnologists, can obtain the most adequate specimen possible and they provide an overview of the current best practices in this area.

Looking towards new approaches to the classification and molecular profiling of lung tumors, Solomides et al. [16] outline a novel algorithm for specimen classification of poorly differentiated NSCLC using microRNA profiling. This technique is readily applicable to cytology cell block material. Young et al. [17] summarize the state of circulating tumor cell (CTC) detection today with particular emphasis on lung cancer and discuss the future applications of CTCs in helping the clinician develop new strategies in patient treatment.

For reasons that are still unclear, EGFR mutations are more commonly found in the Asian population. Ma et al. [18] bring us a perspective from a high incidence area, Hong Kong, with the comparison of EGFR gene mutation testing in surgical and cytology specimens concluding that cytology specimens had a lower detection rate of EGFR mutation (40\%) as compared to surgical specimens $(48 \%)$ but state that the material inadequacy issues in cytology specimens may be overcome by tumor cell enrichment strategies and employment of mutation detection techniques with increased analytical sensitivity. This experience is, interestingly, not universal [19] and the use of the techniques described by Elnekave and Thornton [15], Arcila [14] , and Roy-Chowduri et al. [13] in this issue may address some of the specimen adequacy problems encountered in their practice. 
To aid the cytopathologist in case management and specimen triage, Goyal et al. [20] demonstrate that Tele-Cyt can serve as a powerful alternative, time-efficient strategy for realtime FNA interpretation in a busy practice or in one that includes 'off-site' centers.

Finally, the group from the Mayo Clinic [21] brings the unique perspective that changes in cytology clinical practice due to the decrease in Pap test volumes - expected to further decrease with the new screening guidelines [22] - has resulted in evolving and expanding roles for many cytotechnologists including involvement in DNA ploidy analysis, quantitative immuncytochemistry, FISH, CTC recognition, and molecular oncology testing. As shown in the article by Elnekave and Thornton [15] , the presence of cytotechnologists is essential to some new settings and the expertise of the cytotechnologist may become more crucial in this new cancer era.

The opportunities for cytopathologists to influence therapy, direct management, and uncover strategies in the complex field of cancer are exciting and limitless. Lung cancer has served as a role model in this emerging era. We hope that our readers will find this special edition of Acta Cytologica a useful guide in navigating this new territory.

1. Pao W, Miller V, Zakowski M, Doherty J, Politi K, Sarkaria I, Singh B, Heelan R, Rusch V, Fulton L, Mardis E, Kupfer D, Wilson R, Kris M, Varmus H: EGF receptor gene mutations are common in lung cancers from 'never smokers' and are associated with sensitivity of tumors to gefitinib and erlotinib. Proc Natl Acad Sci USA 2004; 101: 13306-13311.

2 Lynch TJ, Bell DW, Sordella R, Gurubhagavatula S, Okimoto RA, Brannigan BW, Harris PL, Haserlat SM, Supko JG, Haluska FG, Louis DN, Christiani DC, Settleman J, Haber DA: Activating mutations in the epidermal growth factor receptor underlying responsiveness of nonsmall-cell lung cancer to gefitinib. N Engl J Med 2004; 350: 21292139.

3 Paez JG, Jänne PA, Lee JC, Tracy S, Greulich H, Gabrie 1 S, Herman P, Kaye FJ, Lindeman N, Boggon TJ, Naoki K, Sasaki H, Fujii Y, Eck MJ, Sellers WR, Johnson BE, Meyerson M: EGFR mutations in lung cancer: correlation with clinical response to gefitinib therapy. Science 2004; 304: $1497-1500$.

4 Rossi A, Maione P, Colantuoni G, Ferrara C, Rossi E, Guerriero C, Nicolella D, Falanga M, Palazzolo G, Gridelli C: Recent developments of targeted therapies in the treatment of non-small cell lung cancer. Curr Drug Discov Technol 2009; 6: 91-102.

5 Dinan MA, Curtis LH, Carpenter WR, Biddle AK, Abernethy AP, Patz EF Jr, Schulman KA, Weinberger M: Stage migration, selection bias, and survival associated with the adoption of positron emission tomography among medicare beneficiaries with nonsmall-cell lung cancer, 1998-2003. J Clin Oncol 2012; 30: 2725-2730.

6 National Comprehensive Cancer Network: NCCN Guidelines Version 2.2012 Non- Small Cell Lung Cancer. Fort Washington, NCCN, 2011. 
7. Adams J, Wu HH: The utility of fine-needle aspiration in the diagnosis of primary and metastatic tumors to the lung: a retrospective examination of 1,032 cases. Acta Cytologica 2012;56:590-595.

8 Johnson H, Cohen C, Fatima N, Duncan D, Siddiqui MT: Thyroid transcription factor 1 and Napsin A double stain: utilizing different vendor antibodies for diagnosing lung adenocarcinoma. Acta Cytologica 2012;56: 596-602.

9 Moreira AL, Hasanovic A: Molecular characterization by immunocytochemistry of lung adenocarcinoma on cytology specimens. Acta Cytologica 2012;56:603-610.

10 Mino-Kenudson M, Chirieac LR, Law K, Hornick JL, Lindeman N, Mark EJ, Cohen DW, Johnson BE, Jänne PA, Iafrate AJ, Rodig SJ: A novel, highly sensitive antibody allows for the routine detection of ALK-rearranged lung adenocarcinomas by standard immunohistochemistry. Clin Cancer Res 2010; 16: 1561-1571.

11 Savic S, Bubendorf L: Role of fluorescence in situ hybridization in lung cancer cytology. Acta Cytologica 2012;56:611-621.

12 Takeuchi K, Soda M, Togashi Y, Suzuki R, Sakata S, Hatano S, Asaka R, Hamanaka W, Ninomiya H, Uehara H, Lim Choi Y, Satoh Y, Okumura S, Nakagawa K, Mano H, Ishikawa Y: RET, ROS1 and ALK fusions in lung cancer. Nat Med 2012; 18: 378-381.

13 Roy-Chowdhuri SR, Hanson J, Cheng J, Rodriguez- Canales J, Fetsch P, Balis U, Filie AC, Giaccone G, Emmert-Buck MR, Hipp JD: Semiautomated laser capture microdissection of lung adenocarcinoma cytology samples. Acta Cytologica 2012;56:622-631.

14 Arcila ME: Simple protocol for DNA extraction from archival stained FNA smears, cytospins, and thin preparations. Acta Cytologica 2012;56:632-635.

15. Elnekave E, Thornton R: The interventional radiologist's perspective on lung biopsy. Acta Cytologica 2012;56:636-644.

16 Solomides CC, Evans BJ, Navenot JM, Vadigepalli R, Peiper SC, Wang Z: MicroRNA profiling in lung cancer reveals new molecular markers for diagnosis. Acta Cytologica 2012;56:645-654.

17 Young R, Pailler E, Billiot F, Drusch F, Barthelemy A, Oulhen M, Besse B, Soria JC, Farace F, Vielh P: Circulating tumour cells in lung cancer. Acta Cytologica 2012;56:655- 660.

18 Ma ESK, Ng WK, Wong CLP: EGFR gene mutation study in cytology specimens. Acta Cytologica 2012;56:661-668.

19 Rekhtman N, Brandt SM, Sigel CS, Friedlander MA, Riely GJ, Travis WD, Zakowski 
MF, Moreira AL: Suitability of thoracic cytology for new therapeutic paradigms in non-small cell lung carcinoma: high accuracy of tumor subtyping and feasibility of EGFR and KRAS molecular testing. J Thorac Oncol 2011; 6: 451-458.

20 Goyal A, Jhala N, Gupta P: TeleCyP (telecytopathology): real-time fine-needle aspiration interpretation. Acta Cytologica 2012; 56:669-677.

21 Kane LE, Root RR, Voss JS, Caudill JL, Sorenson AM, Colborn LK, Halling KC, Henry MR, Clayton AC, Kipp BR: Molecular diagnostics, personalized medicine, and the evolving role of the cytotechnologist: an institutional experience. Acta Cytologica 2012;56:678-685.

22 Saslow D, Solomon D, Herschel W, et al: American Cancer Society, American Society for Colposcopy and Cervical Pathology, and American Society for Clinical Pathology screening guidelines for the prevention and early detection of cervical cancer. CA Cancer J Clin 2012; 62: 147-172. 